\title{
Turismo e Patrimônio Cultural: da pesquisa ao desenvolvimento
}

Dentre os muito dilemas que cercam a atividade turística no Brasil, o da escala com que estamos trabalhando se engrandece. $\mathrm{O}$ fato de termos dificuldade em superar os 6 milhões de desembarques anuais aprisiona o setor num círculo que é demarcado pela indefinição do lugar do turismo na gestão pública, pela tibieza das políticas públicas em todos os níveis, inclusive no meio empresarial e no terceiro setor, pelo imediatismo do planejamento, formação de pessoal e pesquisa básica. Assim, fica evidente que a articulação tão necessária entre poder público, organizações privadas e universidade é urgente para que, de fato, o turismo passe a ser encarado com a seriedade que até agora faltou.

Em todo o mundo onde o turismo é uma atividade socialmente importante, ganha destaque o Turismo Cultural como uma modalidade que resulta do aprofundamento do conhecimento dos processos históricos, sociais, antropológicos, econômicos, políticos e de organização enfrentados por outras sociedades que se valeram do turismo de massa como instrumento de incremento rápido na economia, quer por consumo de bens e serviços, quer pela geração de empregos ou, na pior situação, ocupações. É nesse sentido que ganha importância a iniciativa do CMU em propor um número dedicado ao Turismo e ao Patrimônio Cultural.

Feita a chamada, inscreveram-se trabalhos de todo o país, cobrindo os mais variados temas e regiões, o que permitiu selecionar iniciativas que destoam da visão clássica que coloca o fato cultural como produto, submetendo-o a impactos que, via de regra, provocam modificações que as artificializam, deslocando-as do meio sociocultural em que foram geradas para um outro, onde só se justificam pela exposição ao visitante. Esse, por sua vez, não tem acesso - porque não lhe é dado - à informação subjacente aos fatos culturais.

Conhecer exaustiva e profundamente cada componente do Turismo Cultural é ampliar o respeito à identidade e ao patrimônio cultural do nosso povo, ampliando o sentido da cidadania. Assim, os textos aqui publicados procuram jogar luz nessa vertente, estimulando o olhar mais atento dos pesquisadores que disponibilizam informações a serem consideradas, não depois de o turismo ter se instalado, mas antes e durante todo o processo de criação, desenvolvimento, consolidação e amadurecimento.

O texto de abertura deste dossiê aborda a patrimonialização da gastronomia, patamar já alcançado em outras culturas que valorizam os saberes e fazeres populares, atribuindo-lhes o destaque que precisam como base cultural sobre a qual outros processos decorreram. No Brasil não será diferente e o respeito é essencial. Segue-se, naturalmente, o texto que enfoca o enoturismo, um dos componentes da vertente gastronômica, que vem se destacando nos estudos mais recentes, de abordagem interdisciplinar, valorizando as paisagens culturais resultantes.

Na sequência, apresentamos artigo com abordagem metodológica sintonizada com o sentido que aqui se quer afirmar. Trata-se da biografia cultural das coisas, proposta como forma de conhecer como atuam, quais valores, sentidos e práticas guardam, produzem e reproduzem os "produtos turísticos", e que oportuniza o tema da educação, que vai se encontrar com as possiblidades do Turismo Rural Paulista, o qual tem apoiado experiências de educação não formal, ampliando e fortalecendo o poder transformador do conteúdo educacional indivisível da atividade do turismo, notadamente na modalidade Turismo Cultural.

O número avança ao apresentar um conjunto de trabalhos que vai ao cerne do problema, isto é, agudiza a necessidade da radicalidade, da historicidade e da contextualização. O caso do município de Cajueiro da Praia (PI) é oferecido à reflexão como evidência de que não se pode fazer mais do mesmo e prosseguir no erro, apontando para a necessidade de um modelo participativo e sustentável de turismo. O Teatro de Mamulengos, recentemente reconhecido como patrimônio imaterial e cultural, surge como um verdadeiro ponto de resistência, assim como o Carimbó do Brasil, difundido na Amazônia, que está no pano de fundo da discussão que procura compreender as relações de componentes da cultura popular com o fenômeno da globalização. Já o patrimônio cultural de Paraty (RJ), destino turístico já consolidado e consagrado, proporciona refletir sobre os efeitos do turismo de massa que "turistifica", embora haja legislação e políticas públicas ali aplicadas há décadas. O Turismo não é uma atividade ingênua e inofensiva como o marketing muitas vezes quer fazer parecer, o que, em si, já é outro equívoco. Tão revelador dos processos subjacentes à falta de pesquisa aprofundada na área é o que o trabalho sobre a Ponte Hercílio Luz, em Florianópolis, aponta como "esquecimento", talvez a mais cruel maneira de perder a memória e, com ela, a identidade.

Com esse recorte, esperamos poder oferecer ao leitor estímulos suficientes para colocarmos a pesquisa na base e na concomitância do planejamento e do desenvolvimento do Turismo Cultural em nossa sociedade. Boa leitura!

Antonio Carlos Sarti ${ }^{1}$ Organizador

1 Professor e coordenador do Curso de Lazer e Turismo da Escola de Artes, Ciências e Humanidades da Universidade de São Paulo (EACH/USP), é bacharel em Turismo pela Faculdade Ibero-Americana de Letras e Ciências Humanas, mestre em Conservação e Manejo de Recursos pela Unesp

- Rio Claro, e doutor em Geografia pela mesma universidade. Trabalha nos temas planejamento turístico, floresta urbana, patrimônio cultural e natural, turismo e arqueologia, planejamento urbano e desenvolvimento sustentável. Desde 2011, é coordenador do Acordo de Cooperação Científica entre a EACH/USP e a Universidade de Girona (Espanha). Também coordena, desde 2012, no Brasil, a Rede UNITWIN - Cátedra UNESCO de Cultura, Turismo e Desenvolvimento, vinculada à Universidade de Paris I Panthéon - Sorbonne. 